\title{
Students' High-Level Thinking Ability In Learning Mathematics In The Era of Pandemic Covid-19
}

\author{
Nok Izatul Yazidah* Dian Fitri Argarini \& Yunis Sulistyorini \\ IKIP Budi Utomo, Malang, Jawa Timur, Indonesia \\ izatulyazidah@gmail.com; kejora.subuh14@gmail.com; yunis.sulistyorini@gmail.com \\ *Corresponding Author: kejora.subuh14@gmailcom | Phone Number: +6282135904972
}

\begin{abstract}
Received: 07 January 2021
Revised: 24 February 2021

Accepted: 12 March 2021

Abstract

High-level thinking skills are an ability that students must have to support how students can think creatively and critically. But what about the learning process in the Covid-19 pandemic era, which can still pay attention to students' higher-order thinking skills. This study aims to describe the learning process in the Covid-19 era in junior high schools in Malang district, and how the students' high-level thinking skills. The data collection methods used were interviews and tests. The research data obtained during the study shows that teachers have maximized the use of online learning platforms to support the virtual learning process recommended by the government. In addition, it was found that the high level thinking ability of junior high school students in Malang district had met the minimum standard set by the researcher at $75 \%$.
\end{abstract}

Keywords: higher order thinking skills; COVID-19;

\section{Introduction}

Higher order thinking skills are one of the important things and are related to the learning process in the classroom. Heong (2011) states that higher order thinking skills aim to improve students' reasoning abilities to solve more complex problems that students find. Adnan (2017) states that higher-order thinking skills will occur when students gain new knowledge and then store, organize, and connect relationships between stored knowledge or information to solve a more complex problem. However, what happened in several schools in Malang district showed something else. After the researchers made several observations in junior high schools, it was found that the teachers were less in stimulating students to use or improve students' higher order thinking skills. One example that shows that the teacher is not maximal in improving students' higher order thinking skills in the classroom is when the teacher still gives simple questions or problems. These simple questions have not been able to stimulate students to use their higher order thinking skills. The questions given by the teacher only require solving in the usual and simple patterns, students only need to mention what is known, what is asked, and answer with a simple formula that has been determined or answer according to the example given by the teacher. This results in students lacking the ability to construct the knowledge they already have. Giving HOTS practice questions is the first alternative solution that is done to improve students' high-level thinking skills in face-to-face learning that occurs in class, because the teacher will be able to stimulate students to construct their knowledge. However, what if the learning that is being carried out is online-based learning?

The last few months until now, the world has indeed been troubled by one phenomenon. This phenomenon is the presence of the Covid-19 corona virus pandemic. All fields in society have changed drastically in terms of implementation and results, including the field of education. Learning that is usually done face-to-face meets face to face in class must be replaced by online learning through virtual meetings assisted by several applications. This may not have had a major impact on schools that have previously carried out online learning, but schools in regions that have never studied with this system have felt different things. Economic factors are one of the obstacles that arise in the online learning model. Through observations and interviews, researchers found that some students did not have devices such as mobile phones or laptops, another obstacle that emerged was an unstable internet network. Some of these problems are certainly factors that researchers must consider in providing solutions to teachers to carry out learning that can improve students' high-level thinking skills. Researchers develop practice questions that can help 
teachers and students to further stimulate students to construct the knowledge they already have. Giving HOTS questions is expected to be able to help students to solve more complicated math problems. What is done is online-based learning ?.

\section{Literature Review}

\subsection{Higher-Order Thinking Skills (HOTS)}

High-level thinking skills (HOTS) are not new to the world of education in Indonesia, but they cannot be said to be familiar in Indonesian education. Since it was first introduced in 2018 by the then Indonesian Minister of Education, Muhajir Effendy, through the design of HOTS based national exam questions. Hairun and Tonra (2020) state that national exam questions in 2018 require students to understand math problems in the context of everyday life. Ernawati (2017) states that when students have high-order thinking skills, these students not only have the ability to memorize but also have the ability to analyze, synthesize, associate, draw conclusions, and come up with new and creative ideas or solutions. This statement is supported by Adnan (2017) which states that High Level Thinking Ability (HOTS) is one of the factors of creative thinking skills and critical thinking abilities. There are several views on indicators of higher-level thinking. If viewed from Bloom's Taxonomy (Krathwohl, 2002) which has six indicators, namely remembering, understanding, implementing, analyzing, evaluating, and creating, the indicators for HOTS are analyzing, evaluating, and creating. The structure of Bloom's taxonomic dimensions can be seen in table 1.

Table 1. Dimens Structure of Cognitive Process Based on Bloom's Taxonomy

\begin{tabular}{lc}
\hline The Cognitive Process Dimension & Explanation \\
\hline Remember & Recognize \\
Recalling
\end{tabular}

HOTS can also be seen from the Marzano dimension, Heong (2011) divides the Marzano dimension into five types of thinking, namely (1) positive attitudes and perceptions about learning, (2) thinking is included in obtaining and integrating knowledge, (3) thinking is included in expanding and filtering knowledge, (4) thinking is included in applying knowledge meaningfully, and (5) producing thinking habits. In this study, the researcher focused on developing questions with a higher order thinking ability approach. The Directorate of Senior High School Development (2017) mentions the characteristics of HOTS questions developed in this study, namely, (1) measuring higher-order thinking skills, (2) based on contextual problems, and (3) using various question forms. According to Lewy (2009) the indicators of the problem to measure HOTS are non-algorithmic, tend to be complex, have more than one possible solution, and require effort to find structures in irregularities.

\subsection{Learning in the Era of the Corona COVID-19 Pandemic}

Since March 2020 until now, Indonesia and the world have been affected by the corona covid-19 virus which is very disturbing. Lots of casualties have fallen as a result of this global pandemic. Almost all sectors in Indonesia have been negatively affected by this pandemic, from the economy, social, politics and education. In the education sector, the Covid-19 pandemic has had a very big impact. Education in Indonesia still uses a face-to-face learning system where teachers and students meet directly and interact with learning activities. However, with this corona virus, learning in Indonesia has changed 180 degrees, learning that is usually done in class is now being implemented virtually. The use of online learning platforms is maximized to support the implementation of learning during this pandemic. The government's suggestion in implementing online learning is certainly one way for the government to reduce the number of victims of this corona virus. As teachers face this, of course they have to modify the learning process that has been 
carried out so far. Modification of this learning process can be done by innovating learning models, learning methods, learning techniques, learning strategies, learning media, or learning evaluation techniques. Mulenga (2020) states that teachers with low teaching abilities will also show low skills in the use of technology in the digital learning process in the era of the COVID-19 pandemic. NCTM (2020) in this pandemic era explains three things that mathematics teachers need to pay attention to when implementing learning in the Covid-19 pandemic era, namely (1) planning the learning process, (2) teaching practices, and advocacy. The learning process plan here means what kind of learning structure is best for students, the learning structure here includes learning models, learning media, learning instruments and other components needed during learning. The second is learning practices, namely what or how the best learning practices to support the student learning process. The third is advocacy which explains how to humanize mathematics learning.

\section{Methods}

This study has several objectives, including (1) describing how the learning process carried out by mathematics teachers in the Covid-19 corona pandemic era, and (2) describing students' high-level thinking skills in mathematics in the era of the corona covid-pandemic. 19. The instruments used in this study were interview guidelines and HOTS questions to measure students' higher order thinking skills. Research subjects in this study were students in junior high schools in 6 junior high schools in Malang district.

\section{Results and Discussions}

The learning process during the current pandemic demands the creativity of teachers, especially mathematics teachers in Malang district. Following the health protocol adopted by the government, the Malang district education office recommends implementing online learning. Through interviews conducted by the teacher with several mathematics teachers in the research school, several findings were obtained regarding the mathematics learning process carried out during the pandemic period. The findings obtained by the researchers included (1) the learning process was carried out virtually in accordance with government recommendations, (2) virtual learning was carried out using learning applications that were commonly used by teachers and students, namely G-classrooms and Z-meetings, (3) The learning process continues to use methods and learning that focuses on student activities. In the virtual learning process that has been carried out, there are also some obstacles experienced by teachers and students during the learning process, namely (1) not all students have devices to support virtual learning such as mobile phones or laptops, (2) Even though students and teachers have received assistance from the government is in the form of internet quota data assistance, but some areas still have internet network problems.

Based on data on the virtual learning process that was carried out and several weaknesses were found in the learning process, teachers and researchers discussed to find solutions so that learning could be maximized. Solutions that teachers can use include, (1) because not all students have devices such as mobile phones or laptops, some students can form groups while doing lessons but still pay attention to government health protocols, (2) the use of other social media such as Whatsapp, YouTube and others so that the learning history can still be stored and can be seen again by students. Forming class groups on Whatsapp is also one way to make it easier for teachers to coordinate classes.

In addition to the virtual learning process, researchers also saw how high-order thinking skills of students were in mathematics subject matter geometry. The assessment of higher order thinking skills is based on cognitive aspects contained in Bloom's taxonomy. Not all aspects of Bloom's taxonomy are used as indicators for assessing higher order thinking abilities, the aspects used are (1) analyzing, (2) evaluating, and (3) creating. The instrument used to see students' higher order thinking skills was HOTS questions that had been developed by the researcher and previously validated. The results of high-order thinking skills of junior high school students in Malang district can be seen in table 2.

Table 2. Results of High Level Thinking Ability of Junior High School Students

\begin{tabular}{|c|c|c|c|c|c|c|c|}
\hline \multicolumn{8}{|c|}{ School } \\
\hline HOTS aspect & $\mathrm{A}(\%)$ & B (\%) & $\mathrm{C}(\%)$ & $\mathrm{D}(\%)$ & $\mathrm{E}(\%)$ & $\mathrm{F}(\%)$ & Average \\
\hline Analyze & 80 & 75 & 80 & 85 & 78 & 80 & 79,67 \\
\hline Evaluate & 75 & 80 & 75 & 80 & 75 & 80 & 77,5 \\
\hline Create & 75 & 80 & 80 & 75 & 75 & 75 & 76,67 \\
\hline Average & 76,67 & 78,33 & 78,33 & 80 & 76 & 78,33 & 77,95 \\
\hline
\end{tabular}

Based on table 2 above, it can be seen that for high thinking skills in general, school A gets a score of $76.67 \%$, school B with a score of $78.33 \%$, school C with a score of $78.33 \%$, school D with a score of $80 \%$, school $\mathrm{E}$ with a score of $76 \%$, while school $\mathrm{F}$ got a score of $78.33 \%$. Then the average score of high-level thinking skills in junior high schools in Malang district is $77.95 \%$. The results of students' high-order thinking skills 
when viewed from each HOTS aspect, it can be seen that the aspect of analyzing the score obtained was $79.67 \%$, for the aspect of evaluating the score obtained was $77.5 \%$, while for the creative aspect the score obtained was $76,67 \%$. From the results of the research that has been obtained, it can be concluded that the high-level thinking ability of junior high school students in Malang district has met the minimum standard set by the researcher, which is $75 \%$.

\section{Conclusions}

Based on the explanation that has been described above, it can be concluded several things, namely (1) The teacher must maximize the use of all online learning platforms to achieve learning objectives by considering students' conditions, (2) Selection of appropriate learning models and strategies will support maximizing the achievement of learning objectives, and (3) the high level thinking ability scores of junior high school students in Malang district, the mathematics subject matter of geometry has met the minimum standard set by the researcher by $75 \%$.

\section{Acknowledgement}

The Authors would like to thank for the support to the Directorate of Research and Service Society, Directorate General Strengthening Research and Development Ministry of Research, Technology and Higher Education that has been support our research through Beginner Lecturer Research scheme. In addition, the authors would like to thank the junior high schools in Malang district who have helped the completion of this research.

\section{References}

Adnan, M., Abdullah, M. F. N. L, Ahmad, C. N. C., Nawi, N. M., \& Ismail, S. (2017). Perceptions of Mathematics Teachers in Higher Order Thinking Skills (HOTS) in Kuala Langat District Secondary School. The Social Sciences, 12 (11): 1963-1965.

Bahtiar, R. S., \& Suryarini, D. Y. (2019). Problem Posing Approach to Optimization Creative Thinking Ability on Mathematics for Elementary Students. International Journal for Educational and Vocational Studies, $1(5), 406-410$.

Ernawati, L. (2017). Pengembangan High Order Thinking (HOT) Melalui Metode Pembelajaran Mind Banking Dalam Pendidikan Agama Islam. PROCEEDINft 1st International Conference on Islamic Civilization and Society: Universitas Islam Darul ‘Ulum Lamongan.

Hairun, Y \& Tonra, W. S. (2020). Comparative Study on High Order Thinking Skills. International Journal of Scientific and Technology Research, 9(3).

Hidayatul, A., Nasution, N., \& Nugroho, P. H. (2020). The Impact of Discovery Learning Models on The Critical Thinking Ability of Students at Middle-School. International Journal for Educational and Vocational Studies, 2(4).

Heong, Y. M., Binti Othman, W., Bin Md Yunos, J., Kiong, T. T., Bin Hassan, R., Binti Mohamad, M. M. (2011). The Level of Marzano Higher Order Thinking Skills among Technical Education Students. International Journal of Social Science and Humanity, 1 (2): 121-125.

Fathoni, F., Amin, S. M., \& Khabibah, S. (2019). Improve Critical Thinking Ability and Motivation in Learning Mathematics Through the Adobe Flash Cs 5.0 Game. International Journal for Educational and Vocational Studies, 1(8), 869-872.

Krathwohl, D. R. (2002). Revision of Bloom's Taxonomy: An Overview. Theory into Practice, 41 (4): 212-218.

Lewy, Zulkardi, \& Aisyah, N. (2009). Pengembangan Soal untuk Mengukur Kemampuan Berpikir Tingkat Tinggi Pokok Bahasan Barisan dan Deret Bilangan di Kelas IX Akselerasi SMP Xaverius Maria Palembang. Jurnal Pendidikan Matematika, 3 (2): 14-28

Mulenga, Eddie M. (2020). Is COVID-19 the Gateway for Digital Learning in Mathematics Education?. Contemporary Educational Technology, 12(2).

National Council of Teachers Of Mathematics, (2020). Moving Forward: mathematics Learning in the Era of COVID-19. Reston, VA: NCTM.

Qadri, L., Ikhsan, M., \& Yusrizal, Y. (2019). Mathematical creative thinking ability for students through REACT strategies. International Journal for Educational and Vocational Studies, 1(1), 58-61. 